\title{
Oyster Mushroom Production in different Agricultural substrates
}

\author{
Somashekhar $^{1 *}$, Radha Banakar ${ }^{2}$ and N Loganandhan ${ }^{2}$ \\ ${ }^{1}$ Krishi Vigyan Kendra, Gonikoppla, Kodagu district-571213, India. \\ ${ }^{2}$ Krishi Vigyan Kendra,Hirehalli,Tumakuru district-572168, India. \\ *Corresponding author
}

\section{Keywords \\ Oyster, Substrate, \\ Biological \\ efficiency, BCR}

\section{Article Info}

Accepted:

15 December 2019

Available Online:

20 January 2020

\section{A B S T R A C T}

Agricultural byproducts which are rich in Lignin content can be utilized for Oyster mushroom production, which feed on these substrates for growth and development of mycelium subsequently fruiting bodies to become Edible mushrooms. Here an effort was made to know the productivity of this mushroom on different Agricultural substrates which are easily available locally viz., Ragi straw (Elosiana corakana L), Areca nut husk (Areca catechu), Coconut husk (Cocus nucifera), Fodder Sorghum Straw (Sorghum bicolor), Guinea grass straw(Megathyrsus maximus) and Paddy straw (Oryza sativa) to know the suitability of these materials on the mushroom productivity in local condition through characters like spawn running(days), period of initiation of pin head formation(days), number of fruiting bodies formed(days). The yield of mushroom, Apart from environmental factors, it also mainly depends on the nature of substrate which is being used. It was evident from the study that, Ragi straw has shown significantly higher yield (83.61\% BE), Less time for Spawn run (17.61 days) and also less time for pin head formation (21.95 days) at KVK Hirehalli, Tumakuru location during 2015-16 of Karnataka state. This study concluded that Ragi straw is having highest Economic benefit with 3.88 BCR and could be a potential substrate in tumakuru location for oyster mushroom cultivation for economic benefit when compared to all other materials studied and also found less time was taken to colonies this fungus ultimately leading to better productivity of mushroom.

\section{Introduction}

Mushroom farming is becoming successful because of its very low inputs. It is estimated that about 300 million tons of fresh mushroom can be produced for just one fourth of world's annual yield of straw (Nita bahl, 2002). In India, Mushroom growing can be highly rewarding because of variable climate where different kinds of mushrooms can be grown in various environmental situation. The technology of mushroom production can be profitably considered in areas where land is a limiting factor and agricultural residues are abundantly available. 
Among the available mushrooms grown, Oyster mushroom can be cultivated easily with average day temperature of $25^{\circ} \mathrm{C}$ which grows on wide variety of agricultural by products, which contain significant lignin content on it. Tewari and sohi (1979) suggested cultivation of Pleurotus sajor caju on paddy straw and maize stalk (1:2) while Pradeepkumar(2017) demonstrated the use of Black gram straw, Soybean straw, Sesame straw and Wheat straw could also be used for the Production of this mushroom.

Based on these observations, it is evident to identify the suitable and substrate which is abundantly available in local area, which could be utilized for mushroom production with higher benefit cost ratio. In krishi Vigyan Kendra, Hirehalli during 2016-17 an effort was made to know the productivity of Oyster mushroom on different substrates like Ragi straw, coconut husk, Areca nut husk, Fodder Sorghum Straw, Guinea grass straw which is abundantly available in local area when compared to Paddy straw.

\section{Materials and Methods}

The selected substrates used for mushroom cultivation used are Ragi straw, Fodder Sorghum Straw, Guinea grass straw and Paddy straw were made into small size of average $4 \mathrm{~cm}$ long while Areca nut husk and Coconut husk were made into small pieces to handle the substrate convenient. These substrates dried before soaking in water for 12 hours later these substrates were sterilized in boiling water for 30 minute in big container separately then sterilized substrates were dried up to moisture retaining $50-60 \%$ by following local method of air drying.

Polypropylene bags with size 30 X $40 \mathrm{~cm}$ bags were used for filling of bags where each treatment bags were filled with $2 \mathrm{~kg}$ of different substrates on dry basis and for each bags 100 gm spawn of variety of Oyster mushroom Arka hu released from IIHR,Bengalure was used for spawning the each treatment. After filling the bags, for each bag, pin holes of $10 \mathrm{~cm}$ apart were done to remove the excess moisture if present inside the substrate. These bags were incubated in dark room with existing ambient temperature of $25^{\circ} \mathrm{C}$. The humidity of $75-85 \%$ was mentioned by using wet gunny bags in the room.

For each treatment, $2 \mathrm{~kg}$ of dry substrates were used with 5 treatments which are replicated in 3 times to analyze the data in Completely Randomized Design (CRD) and the observations were noted for different treatment on growth of mycelium in days on substrates, pin head structure appearance ,maturity of fruiting bodies in days and Mushroom yield( $\mathrm{Kg})$.

Biological efficiency (\%) was calculated using the following equation (Jwanny et al., 1995): Biological efficiency $=(A / B) \times 100$, where $A$ is weight of dry mycelium, $B$ is weight of the dry substrate. Statistical analysis all samples were carried out in triplicate. The data were analyzed by Excel statistical functions using Microsoft Office XP software the Statistical Package. Values are presented as means \pm standard error of the mean (SEM). Differences at $\mathrm{P} \leq 0.05$ were considered to be significant.

Benefit Cost Ratio (BCR) for each treatment was calculated based on the cost involved in spawn, substrate, and other materials used and the income from the Mushroom produced and sold@ 200/kg.

\section{Results and Discussion}

Different substrates were allowed for spawn running and results were discussed with following heads. 


\section{Spawn Running}

For completion of spawn running (Table -1) for all the substrates, it ranges from 17.6 to 23.63 days with 1.53 days of critical difference among the raw materials used for mushroom production.

\section{Initiation of Pin Head formation}

After complete spawning in each treatment, pin head structures were observed which ranged between 21.92 days to 31.49 days (Table-1).Coconut husk (31.49 days) and areca nut husk (28.63 days) significantly took more time when compared with other substrates where lowest time period was observed for ragi straw with 21.92 days. This character is direct contributor for the productivity for each substrate used and it ranged between 24.66 to 30.66 days.

\section{Fruiting body formation}

This is the final mushroom quantity harvested during mushroom cultivation. Fruiting bodies generally appear after 4-5 days of pin head initiation. Range for this character for different substrates is between 26.37 to 36.61 days. Nita Behl(2002) reported 29 days for fruiting body formation in paddy straw as a substrate.

Table.1 Effect of Different Agricultural substrates on Oyster mushroom growth and Development

\begin{tabular}{|l|l|c|c|c|c|}
\hline $\begin{array}{l}\text { SI } \\
\text { no }\end{array}$ & Substrates & $\begin{array}{c}\text { Completion } \\
\text { of spawn } \\
\text { running (In } \\
\text { days) }\end{array}$ & $\begin{array}{c}\text { Days for } \\
\text { initiation of } \\
\text { pin head } \\
\text { formation }\end{array}$ & $\begin{array}{c}\text { Fruiting } \\
\text { bodies } \\
\text { formation } \\
\text { (Days) }\end{array}$ & $\begin{array}{c}\text { Average no } \\
\text { of Fruiting } \\
\text { bodies }\end{array}$ \\
\hline $\mathbf{1}$ & Ragi straw & 17.60 & 21.92 & 26.37 & 28.63 \\
\hline $\mathbf{2}$ & Areca nut husk & 22.50 & 28.63 & 33.42 & 17.65 \\
\hline $\mathbf{3}$ & coconut husk & 23.63 & 31.49 & 36.61 & 12.63 \\
\hline $\mathbf{4}$ & Fodder sorghum straw & 19.30 & 23.97 & 29.50 & 24.27 \\
\hline $\mathbf{5}$ & Guinea grass straw & 18.60 & 24.57 & 28.60 & 21.35 \\
\hline $\mathbf{6}$ & Paddy straw & 18.73 & 22.92 & 26.47 & 24.55 \\
\hline CD $@ \mathbf{5 \%}$ & 1.53 & 1.006 & 2.6 & 1.76 \\
\hline
\end{tabular}

Table.2 Oyster Mushroom yield (Average) in different Substrates and their biological efficiency along with cost benefit ratio

\begin{tabular}{|l|l|c|c|c|}
\hline SI no & Substrates & $\begin{array}{c}\text { Average yield of } \\
\text { Mushroom (kg) }\end{array}$ & $\begin{array}{c}\text { Biological } \\
\text { Efficiency (\%) }\end{array}$ & BCR \\
\hline $\mathbf{1}$ & Ragi straw & $1.41^{\mathrm{a}}$ & 70.4 & 3.90 \\
\hline $\mathbf{2}$ & Areca nut husk & $0.77^{\mathrm{c}}$ & 38.4 & 1.77 \\
\hline $\mathbf{3}$ & Coconut husk & $0.68^{\mathrm{c}}$ & 34.2 & 1.69 \\
\hline $\mathbf{4}$ & Fodder sorghum straw & $1.13^{\mathrm{b}}$ & 56.6 & 2.30 \\
\hline $\mathbf{5}$ & Guinea grass straw & $1.20^{\mathrm{b}}$ & 60 & 2.72 \\
\hline $\mathbf{6}$ & Paddy straw & $1.23^{\mathrm{b}}$ & 61.6 & 3.25 \\
\hline CD @ 5\% & 0.2 & 3.32 & 0.12 \\
\hline
\end{tabular}




\section{Number of Fruiting Bodies}

Number of Average sized/medium sized fruiting bodies emerged from each were counted and among all the substrates used, Ragi straw had given maximum(28.63) number of fruiting bodies(Table-1) followed by paddy straw(24.55) while lowest numbers were observed in coconut husk(12.63).

\section{Oyster Mushroom Yield}

Mushroom was harvested in two batches for the different substrates used in the study. Among them, Ragi straw yielded $(1.41 \mathrm{~kg})$ maximum yield significantly compared to other substrates. Yield from Fodder sorghum straw (1.13), Guinea grass straw (1.2) and paddy straw (1.23) was recorded without significant difference among them. While Areca nut husk $(0.77 \mathrm{~kg})$ and Coconut husk $(0.68 \mathrm{~kg})$ substrate gave less mushroom yield.

Tupatler and Jadhao (2006) had shown studies on different Agricultural wastes like Wheat straw, Paddy straw, Soybean stalk and concluded that paddy straw has given $1.22 \mathrm{~kg}$ of mushroom yield followed by $1.10 \mathrm{~kg}$ for soybean straw for $2 \mathrm{~kg}$ of dry substrates. Differences in the oyster mushroom could be attributed to lignolytic and cellulytic activity exhibited by the different agricultural substrates.

\section{Biological efficiency (\%)}

Highest Biological efficiency was shown by Ragi straw(70.4\%) (Table: 2) followed by paddy straw (61.6) and Guinea grass straw (60.0\%). Dehoriy and Vyas (2013) concluded that substrate soybean straw concluded that soybean straw was more efficient for this Oyster mushroom production with $\mathrm{BE}$ value 93.3\%. Das et al.2000 reported Pleurotus Sajar Caju was found to utilize all the agricultural substrates which are locally available and can be utilized for mushroom cultivation.

Agricultural wastes are rich in lignin cellulosic components which are difficult to breakdown, but can easily be done through mushroom cultivation. Mushrooms are freshly fungi, spore bearing fungi bodies which are produced above ground on soil. They often refer to fruiting body of the gill fungi, which do not contain chlorophyll like green plants and as a result cannot manufacture food by their own. They are very nutritious products that can be generated from lignocellulosic waste materials.

The bioconversion of agricultural wastes into a value added products is a good mean of their use. The property of edible mushroom fungi to convert complex organic compounds into simpler one's is used to transform the useless agricultural waste into valuable product (Kamthan R and Tiwari 2017).

Based on this study, Ragi straw which is abundantly available in Tumakuru district could be a potential agricultural substrate in this location as it is sowing highest mushroom yield with $70.4 \%$ biological efficiency as well BCR is 3.90, while Areca nut husk and coconut husk even though abundantly available has resulted in lower as well as lesser BCR due to time required for colonization of mushroom fungi as lesser surface area is available.

\section{References}

Jwanny EW, Rashad MM, Abdu HM. 1995. Solid-state fermentation of agricultural wastes into food though Pleurotus cultivation. Appl. Bioch. Biotech., 50: 71-78.

Kamthan R, Tiwari I (2017) Agricultural Wastes- Substrates For Mushroom Exp Biol. Vol. 7 No. 5:31. 
Tupatkar P N and Jadhao S M (2006). Effect of different substrates on yield of oyster
Mushroom (Pleurotus sajar caju). Agri Sci Digest 26:224-226.

\section{How to cite this article:}

Somashekhar, Radha Banakar and Loganandhan. N. 2020. Oyster Mushroom Production in different Agricultural substrates. Int.J.Curr.Microbiol.App.Sci. 9(01): 1468-1472.

doi: https://doi.org/10.20546/ijcmas.2020.901.163 